TREE-RING RESEARCH, Vol. 62(2), 2006, pp. 51-65

\title{
TREE RINGS AND THE AGING OF TREES: A CONTROVERSY IN 19TH CENTURY AMERICA
}

\author{
CHRISTOPHER H. BRIAND \\ Department of Biological Sciences \\ Salisbury University \\ Salisbury, MD 21801, USA \\ SUSAN E. BRAZER \\ Blackwell Library \\ Salisbury University \\ Salisbury, MD 21801, USA \\ and \\ JEANNINE M. HARTER-DENNIS \\ Department of Agriculture \\ University of Maryland Eastern Shore \\ Princess Anne, MD 21853, USA
}

\begin{abstract}
During the late 19th Century there was considerable debate in the United States among members of the legal profession, the general public and even some scientists about the validity of using tree rings to determine tree age. In an earlier boundary dispute case in Maryland (1830) the Honorable Theodorick Bland rejected the use of tree rings to establish the date when a purported witness tree was marked with an identifying blaze. Bland did not believe that there was enough scientific evidence or legal precedent to support this idea. A review of the current scientific literature of the time, however, indicates that most scientists, especially in Europe, accepted that tree rings could be used to determine age. In the United States, however, this idea was debated, particularly in the late 19th Century, in both the popular press and scientific publications. The main argument of opponents such as A. L. Child was that the number of tree rings was often wildly in excess of the known age of the tree. These inconsistencies were likely because of the inexperience of the observer, mistaking earlywood and latewood for separate rings, and the presence of a small number of false rings, sometimes called secondary rings. The great ages reported for the giant sequoias may have also raised doubts among the public. Among scientists, however, the relationship between ring number and tree age and between ring width and climate became widely accepted. Several cases heard in both Federal and State Courts as well as Bernhard E. Fernow's Age of Trees and Time of Blazing Determined by Annual Rings laid to rest any doubt of the relationship between tree rings and age in temperate forests, i.e. one ring equals one year's growth, and showed that the date when a witness tree was blazed could be easily determined from a cross-section of the trunk.
\end{abstract}

Keywords: boundary disputes, 19th Century, tree rings, witness trees.

\section{INTRODUCTION}

"the 'rings' in a tree stump are not a safe guide as to the tree's age. That idea is a popular superstition." (Yates County Chronicle [New York] 1884)

In the early part of the 20th Century, a series of pioneering papers was published, where the width of tree rings was used to infer past climatic conditions (Douglass 1909, 1914, 1920, 1922, 1929). Thus the new science of dendrochronology was born. This work was predicated on the understanding that a tree ring represented a single year's growth and that these rings represented a datable chronology. In 19th Century America, however, 
the idea that the age of a tree could be determined by counting the number of rings in a transverse section of the trunk was often controversial. An article in the Naugatuck Daily News [Connecticut] (1897) stated that: "Although forestry experts in Europe for more than a century have held the theory of determining the age of a tree by the ring markings to be absolutely reliable, many attempts have been made in this country [the United States] to disprove it." This was not just a question for academic debate, but had practical implications for the identification of witness trees in boundary disputes. Both the traditional "Metes and Bounds" surveys (Figure 1), used in the eastern United States ${ }^{1}$ before independence, and the "Rectangular System" of land surveys adopted by the United States Continental Congress (1785) regularly used witness trees (Figures 2 and 3) as landmarks to help delineate property boundaries: "The lines shall be measured with a chain ${ }^{2}$; shall be plainly marked by chaps [chops] on the trees."

In a letter to The Nation (1888a) Bernhard E. Fernow, Chief of Forestry for the Division of Forestry, United States Department of Agriculture wrote:

\footnotetext{
"The discussion on the age of the Sequoias has brought up the question of the truthful record of age as indicated by so-called annual rings. While the former question is one of curiosity, the latter is one of decidedly practical importance, as its answer may affect the property rights of any citizen who is unfortunate enough to have to rely for the boundary lines of his land claims on the blazes with which a backwoods surveyor has marked the course of the survey lines. For, as is well known, the courts have had often to decide the priority of a survey and therefore title to land solely upon the evidence of a surveyor's overgrown mark made a certain definite number of years ago, the "annual ring" deciding the time of survey."
}

The importance of preserving these trees as property markers was recognized by Congress (Act of June 10, 1896; 29 State., 321). This act made it illegal to "cut down any witness tree or any tree blazed to mark the line of a Government survey."

\footnotetext{
${ }^{1}$ Connecticut, Delaware, Georgia, Kentucky, Maine, Maryland, Massachusetts, New Hampshire, New Jersey, New York, North and South Carolina, Pennsylvania, Rhode Island, Tennessee, Texas, Vermont, Virginia (Geo. A. Ogle \& Co. 1903).

${ }^{2}$ The length of a chain is 66 feet $(20.1 \mathrm{~m})$, and is divided into 100 links.
}

The offender faced a fine "not exceeding two hundred and fifty dollars" or imprisonment of "not more than one hundred days" (qtd. in Pinchot 1908).

The aim of this work is to trace the struggle in America, during the 19th Century over the legitimacy of using tree rings to determine the age of trees. Whereas the aging of trees by tree rings in Europe was commonly accepted for several centuries (Da Vinci 1651; Grew 1682; Leeuwenhoek 1683, 1798, 1807; Duhamel du Monceau 1758; Hill 1770; Kalm 1773; Smith 1814), there was resistance in the United States from certain members of the legal profession among others.

We begin by discussing a boundary dispute heard in the Maryland High Court of Chancery in 1830. This case is particularly illuminating, as it illustrates the resistance to and lack of understanding of the current literature of that time, and was our entry into this fascinating topic. A review of the arguments put forth both against and in favor of using tree rings to establish tree age is presented next (1830-1900). The judicial recognition of using tree rings to age trees is explored by examining several cases in both state and federal courts (1862-1903). Finally the landmark writings of Bernard Fernow, which provided acceptable scientific legitimacy in the United States for using tree rings to age trees, are discussed. Source materials included books, journals both scientific and general, government reports and legislation, court cases, letters, newspaper articles and letters to the editor published between 1651 and 1910 .

\section{THE HIGH COURT OF CHANCERY- MARYLAND 1830}

The resolution of a boundary dispute in western Maryland, Joseph Patterson and Evan Ellicot v. Robert M'Causland (Patterson v. M'Causland), hinged on the determination of whether a marked black oak was the witness tree called upon to partially delineate a tract of land known as Jolly's First Attempt (Maryland, High Court of Chancery 1841). This tract was laid out in 1791. Patterson and Ellicot argued that the tree in question could not have been the tree marked in 1791 as "there appears to have been added, by natural growth, 


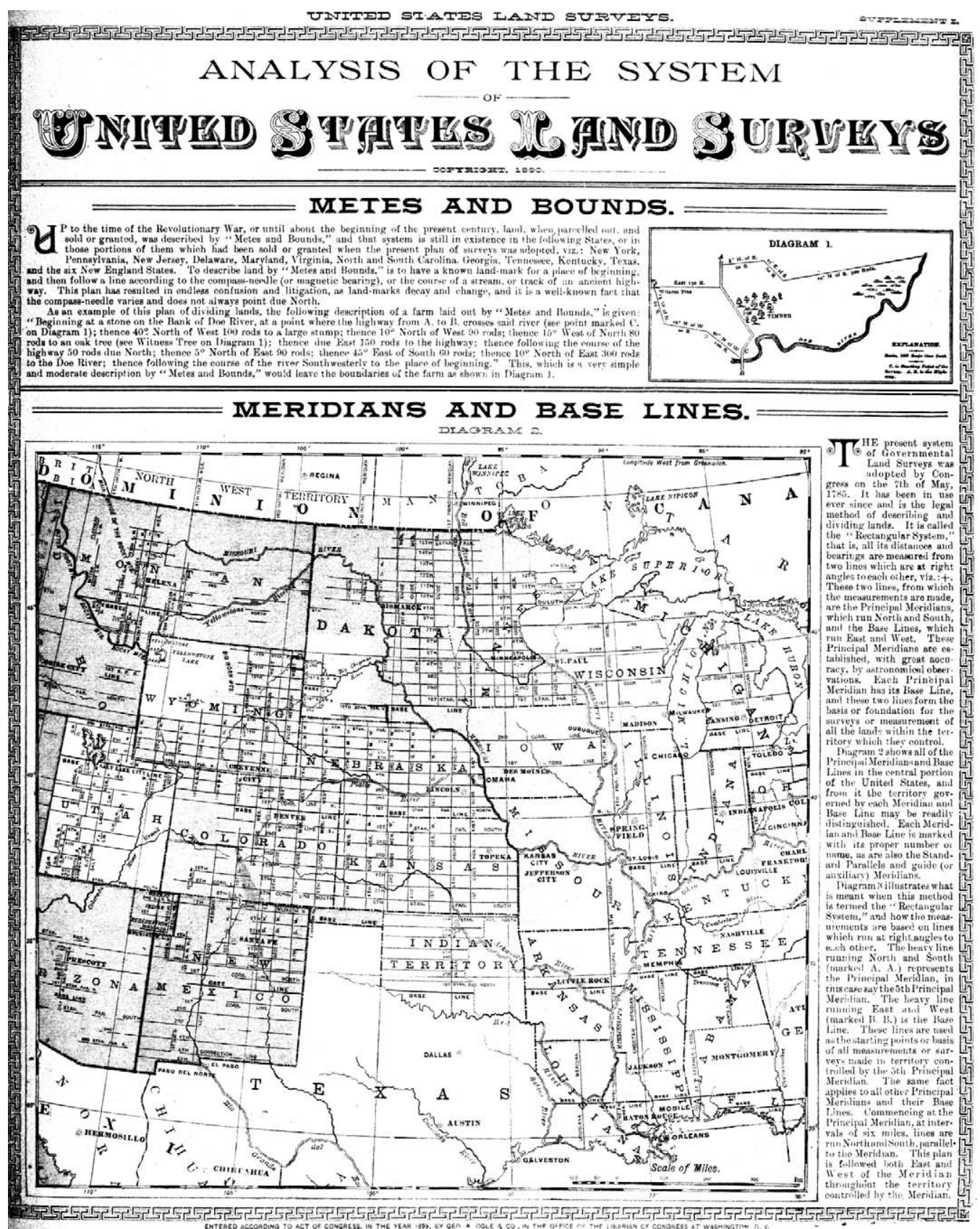

Figure 1. "farm laid our by 'Metes and Bounds' [ . . ]: 'Beginning at a stone on the Bank of Doe River, at a point where the highway from A. to B. crosses said river (see point marked C. on Diagram 1); thence $40^{\circ}$ North of West 100 rods to a large stump; thence $10^{\circ}$ North of West 90 rods; thence $15^{\circ}$ West of North 80 rods to an oak tree (see Witness Tree on Diagram 1); thence due East 150 rods to the highway; thence following the course of the highway 50 rods due North; thence $5^{\circ}$ North of East 90 rods; thence $45^{\circ}$ East of South 60 rods; thence $10^{\circ}$ North of East 300 rods to the Doe River; thence following the course of the river Southwesterly to the place of beginning." From Geo. A. Ogle \& Co. (1903). The length of a rod is 51/2 yds or 161/2 ft. $(5.03 \mathrm{~m})$. 


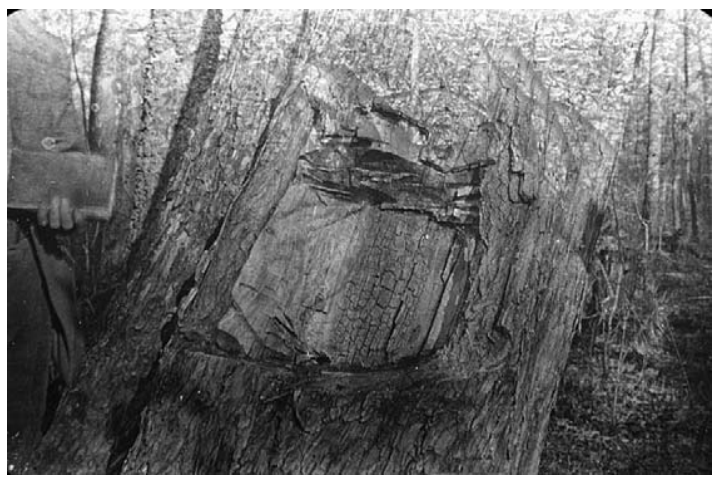

Figure 2. "Close view [of an] Ulmus americana, [an] 1846 Witness Tree, Arkansas" (Lantern slide; American Environmental Photographs Collection, [AEP-ARS20], Department of Special Collections, University of Chicago Library.).

only twelve concentric layers of wood outside of, and since the chop mark was made." Thus, "the black oak, shewn [shown] by those witnesses, upon resurvey, could not have received the chop mark so long ago as the year 1791 , when the tract called Jolly's First Attempt was laid out; and consequently, could not be the marked black oak called for in the certificate of that tract."

This case was heard by the Honorable Theodorick Bland, Chancellor of Maryland. Bland was a highly respected judge, whose rulings demonstrated his "extraordinary learning, ability and versatility" and whose opinions sometimes "read more like treatises upon the various legal questions presented by the case, than a judicial statement on the grounds upon which they are decided" (Marbury 1905). Patterson v. M'Causland was no exception.

In a lengthy opinion, Bland began: "The point then to be here determined is, whether, in the growth of trees, a concentric layer of wood under the bark is a regular and invariable annual formation or not?" In researching this question Chancellor Bland consulted numerous judicial decisions as well as several botanical and anthropological texts, including Darwin's Phytologia (1800), Michaux's The North American Sylva (1817-1819), Rees' thirty-nine volume Cyclopaedia (1819), Eaton's Botanical Grammar and Dictionary (1828), McCulloh's (1829) Researches, Philosophical and Antiquarian, Concerning the Aboriginal History of

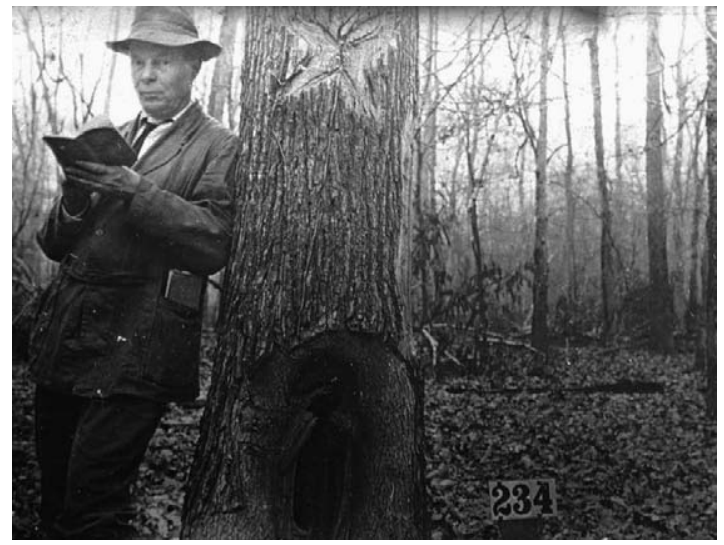

Figure 3. "Good bark study [of a] Quercus lyrata, [an] 1847 Witness Tree, Arkansas" (Lantern slide; American Environmental Photographs Collection, [AEP-ARS19], Department of Special Collections, University of Chicago Library.).

America, and Roget's Animal and Vegetable Physiology $(1834) .{ }^{3}$ Based on his readings Bland wrote:

\begin{abstract}
"From what has been said, it appears, then, that some mere annual roots, and the roots of all trees, as well as the wood of most of our forest trees, exhibit the appearance in a transverse section, of having been formed by a succession of concentrical layers; that the wood of a variety of trees which are only the growth of the torrid zone, are obviously formed in the same way: and therefore, that such concentrical layers cannot with certainty be pronounced to be the result of a succession of summer growths; or any one of them to be the growth of only one year, or of any other given space of time. It also appears, that the wood of some trees, of the growth of the temperate as well as of the torrid zone, does not, in a transverse section of it, exhibit the least appearance whatever of any concentrical layers."
\end{abstract}

He then ruled that "the testimony of the witnesses stands in all respects unimpeached and the line must be carried to the black oak, as called for and proved." The ruling was therefore in favor of the defendant Robert M'Causland and Patterson and Ellicot were required to pay the court costs of both parties.

Chancellor Bland may have come to an entirely different decision if he had access to or used a broader literature base in formulating his decision. Numerous books and articles published before 1830 discussed the annual nature of tree rings, including: Dendrologia (Mitchell (1827), An Intro-

\footnotetext{
${ }^{3}$ Publication dates were not given in Bland's opinion.
} 
duction to Systematic and Physiological Botany (Nuttall 1827), Elementary Principles of Carpentry (Tredgold 1820), Introduction to Physiological and Systematic Botany (Smith 1814), The Economy of Nature (Gregory 1798), Of the Oak. The Nature of it's Production; the Different Degrees of Goodness in Oak Timber; and the Causes of that Difference (Leeuwenhoek 1798); Planting and Ornamental Gardening (Marshal 1785), Travels in North America (Kalm 1773), The Construction of Timber, From Its Early Growth, Explained by the Microscope, and Proved by Experiments (Hill 1770), La physique des arbres (Duhamel du Monceau 1758), The Anatomy of Plants (Grew 1682), Letter from Mr. Anthony Leewenhoeck of Delft to Mr. R.H. concerning the appearances of several woods, and their vessels (Leeuwenhoek 1683), Treatise on Painting (Da Vinci 1651).

\section{AFTER 1830}

Although many newspaper articles throughout the later half of the 19th Century casually reported the age of trees as determined by counting the number of tree rings (The Coshocton Democrat [Ohio] 1863, 1871; The Defiance Democrat [Ohio] 1869; The Stevens Point Journal [Wisconsin] 1878, 1885; Daily Gazette and Bulletin [Pennsylvania] 1879, 1894; The Decatur Daily Review [Illinois] 1879; Marion Daily Star [Ohio] 1881, 1882a,b; The Decatur Daily Republican [Illinois] 1882; The Lafayette Advertiser [Louisiana] 1894), other reports still discounted their use.

\section{Arguments Against}

The following was published in the "Journal" section of the Hartford Daily Courant [Connecticut] (1856):

\footnotetext{
"It is a popular belief that the age of trees can be determined by the "rings" or grains that overlie each other in their trunks. Mr. Joshua Howard of Maryland, disputes this fact. He says that the rings counted on the section of the tree are not of annual growth, but are formed one at every full moon in the growing season, and in the latitude of Maryland five in a year. This he has frequently proved by felling young trees, the age of which he knew.-The extraordinary age given to trees by the popular rule has made many persons doubt whether it is true."
}

Another staunch opponent of the theory of an- nual rings was Dr. A. L. Child who wrote and was cited in a number of publications in the late 19th Century (Child 1882, 1883; Smith 1884; Montgomery 1884; Penhallow 1885; Brooklyn Eagle [New York] 1887; Sandusky Daily Register [Ohio] 1891). Child was a medical doctor with an interest in natural history. He made meteorological observations for the Smithsonian Institution, served as a Probate Judge (Andreas 1882) and appears to have been a charter member of the Nebraska State Board of Agriculture (Sheldon 1904). In Popular Science Monthly, Child (1882) reported that 12year old red maples (Acer rubrum L.) that he had planted from seed exhibited "thirty-five to forty concentric rings." He did add: "True, I could select twelve more distinct ones between which fainter and narrower, or sub-rings, appeared." Red maple has diffuse porous wood that can make the delineation of annual rings more difficult. In his 1883 article in Popular Science Monthly Child quoted the Honorable James J. Wilson of Vermont who informed him "that at a trial in the District Court at Woodstock, Vermont, on a disputed line based upon a cut on a hemlock-tree, a section of the tree embracing the cut was produced in court, and the rings outside the cut counted up from forty to fifty, while those on the opposite side were only nine or ten!" The court decided, "the rings were not a sure indication of the age of the tree." Several 19th Century legal manuals also referenced Bland's ruling in relation to determining tree age, including The Principles of the Law of Evidence (Morgan 1882) and A Treatise upon the Law of Pleading (Bliss 1894).

Child also quoted the "Hon. J. T. Allan, of Omaha, Superintendent of tree-planting for the Union Pacific Railroad Company" who said that "Any intelligent man, who has given any attention to this matter of yearly tree-growth, knows that the rings are no index of a tree's age." Child's major concern appeared to be the presence of what he termed "intermediate rings or sub-rings [false rings]" caused by "sudden and more or less frequent changes of weather and requisite conditions of growth", which could not be distinguished from true annual rings thus making accurate aging nearly impossible. He also questioned whether trees grown under constant conditions such as a con- 
servatory produced "any concentric rings?" In response to Child's second article, Baldwin (1884), in the Correspondence section of the same journal wrote:

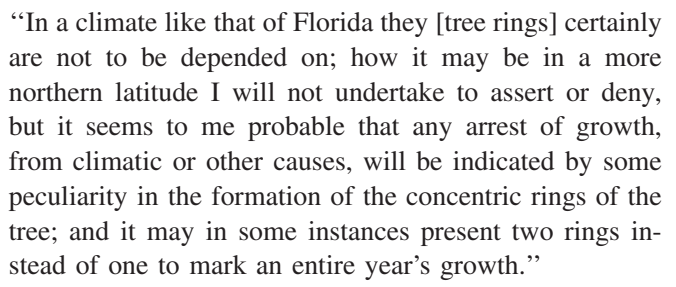

R. W. Furras ${ }^{4}$ was quoted in the Brooklyn Eagle [New York] (1887) as saying that: "Concentric rings or annual rings, which were once accepted as good legal evidence, fail, except where climate, soil, temperature, humidity and all other surroundings are regular and well balanced. Otherwise they are mere guesswork." In numerous trees of known age, Furras had found that ring counts did not match the tree's age ${ }^{5}$. The same article stated that: "Another expert says that all our Northern hard woods make many rings a year, sometimes as many as twelve."

In The Nation, Caroline Healy Dall (1887) disputed the great ages attributed to the giant sequoia. Dall lectured and wrote extensively on women's rights, was a founder of the American Social Science Association (1865), and was at various times a lay minister and teacher. She wrote "that it was absurd to suppose that those trees were more than a thousand years old." Dall went on to opine: "In a climate which produces two or three crops a year of most vegetables, there is nothing to prevent the formation of more than one ring in twelve months." She also quoted from Charnay's (1887) The Ancient Cities of the New World, who reported that ruins could not be dated accurately using tree rings, as this method "was based on the erroneous

${ }^{4}$ Likely Robert W. Furnas, special agent of the United States Department of Agriculture and Governor of Nebraska (Anonymous 1904).

5 "Mr. Furras found twelve rings in a black locust six years old, twenty-one rings in a shell bark hickory of twelve years, ten rings in a pig hickory of six years, eleven rings in a wild crabapple of five years and only twenty rings in a chestnut oak of twenty-four years. An American chestnut of only four years had nine rings, while a peach of eight years had only five rings." notion that a concentric circle represents one year, whereas I ascertained that in a tropical country nature never rests." 6

Professor Hartig (The Olean Democrat [New York] 1890) was said to believe that "a count of the annual rings of a tree when cut three or four feet from the ground may not give the accurate age of it." Hartig wrote that trees growing in crowded conditions would not produce enough food "to provide for a sheet of cambium all over the tree, the growth stops before reaching the bottom, and the ring which is found twenty feet up the trunk may fail altogether before it reaches the ground."

In an article entitled Rings as Marks of Tree Growth, the Sandusky Daily Register [Ohio] (1895) reported: "Mr. James Stewart, one of the most intelligent horticulturists of the south, says in a note on the annual ring growth of trees that he knew a case of a tree 25 years old which, when cut down, exhibited 75 concentric rings." Clearly not everyone was convinced of the veracity of one ring equaling one year's growth.

\section{Arguments in Favor}

Numerous books and articles published throughout the 19th Century described the annual nature of tree rings (for example: Bowman 1832; Twining 1833; Babbage 1838; Anonymous 1844; Gray 1853, 1876; Anonymous 1859; Murchison 1861; Lewis 1873; Britton 1879; New York Times [New York] 1882; Dudley 1886; Anonymous 1890). In The Longevity of Trees (Anonymous 1844), it was pointed out that "in nearly all trees except Palms and their allies, the age may be directly ascertained by counting the annual rings on a cross section of the trunk."

Variation in ring width was also discussed by many authors; ascribing this phenomenon to "the more or less flourishing state of the plant during the years in which they were formed" (Babbage 1838), "the supply of water" (Anonymous 1859), "the effects of temperature, moisture, winds, and other variable elements of the climate" (Hough 1878), "conditions of soil and of the seasons"

\footnotetext{
${ }^{6}$ In many tropical species annual rings are formed (Worbes 2002).
} 
(E.L., Sr. 1879), “influence of meteorological conditions [...], particularly with reference to rainfall." (Penhallow 1885), and "varying conditions of growth in different seasons, and marked variations [. . . ] in trees from different localities" (Dudley 1886).

False rings often made obtaining an accurate age difficult. In the Ninth Bridgewater Treatise (1838), Charles Babbage, who served as Lucasian Professor of Mathematics at Cambridge University from 1828 to 1839, wrote: "Each ring may, in some trees, be observed to be subdivided into others, thus indicating successive periods of the same year during which its vegetation was advanced or checked." Fred W. Card (1898), Associate Professor of Horticulture, at the University of Nebraska, noted that false rings might be the result of "depredations of insects which defoliate the tree, or periods of drought which check its growth" Card attempted to induce false rings through bark removal and defoliation, with little success. He concluded:

"This experiment, it should be noted, does not contradict the general opinion that there may be more than one ring formed in one year, but it does seem to indicate that a greater interference with the normal conditions of growth is needed to produce that effect than has often been supposed."

Along with false rings, very narrow rings can be difficult to distinguish: "The record is sometimes illegible or nearly so, but it is perfectly authentic; and when fairly deciphered, we may rely upon its correctness" Anonymous (1844). These "thin rings, which can scarcely be distinguished by the naked eye, denote dry ones [years]." (Anonymous 1859; quoting J. Kuechler of Texas). Nathaniel Lord Britton, also addressed the difficulty of always getting an accurate ring count. In Notes on the Relative Age and Dimensions of a Number of Different Trees, Britton (1879) wrote: "The age has been determined [...] by counting the annual rings in the case of felled trunks, which latter may be a year or two in error in a few cases, owing to the difficulty in counting when the rings are obscure or very close together."

Responding to Child's 1882 article in Popular Science Monthly, in a letter to the editors, Smith (1883), a lawyer, who had been involved in a num- ber of boundary dispute cases in Virginia arising from surveys done between 1794 and 1857 wrote:

"the hack made by the surveyor to the outside of the tree [. . .] corresponded with the dates as they appeared on the returns made by the surveyor, showing as many rings as years had elapsed from the date of the survey, thus proving that for each year of the life of the tree an additional concentric ring had been added."

Smith went on to say that Judge N. H. Swayne, who was "familiar with these facts" would be able to corroborate his statements.

In response to Dall's letter, concerning the reported ages of the giant sequoia in The Nation, Cornelius Breach Bradley (1887), Professor of Rhetoric at the University of California at Berkeley and a founding member of the Sierra Club where he served on the Board of Governors from 1894-1910, replied: "perplexities and freaks of growth in the hot-house climate of tropical America are complacently cited as proof that the same kind of uncertainty attends upon growth on the flanks of our Sierra Nevada, where seasons, though not so extreme, are as sharply delimited as they are in Maine." Bradley went on to write: "It seems a pity that science should be continually perplexed and hindered by its apparent votariesas, indeed, it is - through the presentation, with all the authority which print can give, of uninformed assertion and inconsequent reasoning."

David Pearce Penhallow (1885), Professor of Botany at McGill University and Director of the Montréal Botanical Gardens who published close to 200 papers, specializing in the study of living and extinct conifers (Jeffrey 1911), decided to study the relationship between tree age and ring number noting that: "there appears to be nothing on record of a systematic and exhaustive character to permit the deduction of a general law." He reported that in 13 samples of young trees (7-12 years old), $38 \%$ showed an exact correspondence between tree age and ring number, while $31 \%$ had more rings and $31 \%$ had fewer rings than predicted; ring number varying by one or two years. Excess rings were attributed to "the development of secondary rings [false rings]." Penhallow concluded that: "In cold climates, rings of growth are an approximately correct index of age, but in warm climates they are of little or no value in this re- 
spect." However: "Even in cold climates there is not an absolute correspondence between the number of rings formed and years of growth."

\section{EARLY ATTEMPTS AT DATING ARCHAEOLOGICAL SITES AND GEOLOGICAL EVENTS}

Although Bland had dismissed the idea of determining the antiquity of archaeological sites by means of tree rings, a number of reports were published beginning in the late 18th Century which relied on this technique. Determining the age of trees growing on a ruin allows only for the determination of a terminus ante quem, thus underestimating the age of the site (Nash 1999, 2003). For example, Fewkes (1915) counted the number of tree rings of a juniper growing on the ruins of the Sun Temple at Mesa Verde. He determined that the tree was 360 years old and had "begun to sprout shortly after 1540." Fewkes went on to say: "How much time elapsed between the laying of the foundation-stones and the time the top of walls fell to form a mound twelve feet high no one can tell." Later tree-ring analysis of house beams indicated that building at Mesa Verde had ended in the late 13th Century; the Anasazi abandoned this site shortly thereafter (Douglass 1929; Haury 1934; Getty 1935a, 1935b). Although inaccurate, these studies do, however, represent the first attempts at an "age" determination and provide evidence archaeologists understood that a tree ring represented one year's growth.

The Rev. Dr. Manasseh Cutler described the dating of earthworks in Ohio in the late 18th Century (qtd. in Putnam 1890) as follows: "The only possible data for forming any probable conjecture respecting the antiquity of the works, I conceived, must be derived from the growth upon them. By the concentric circles, each of which denotes the annual growth, the age of the trees might be ascertained." The largest sound tree ranged in age from 300 to 400 years, while a hollow tree, had 463 annual rings and was therefore even older. McCulloh (1829) in his Researches, Philosophical and Antiquarian, Concerning the Aboriginal History of America wrote that "fortifications or mounds" in Ohio were "in numerous instances overgrown with trees, whose age as estimated from the concentric rings on their stumps, appear to be three or four hundred years old." With reference to McCulloh's "dating" of Indian mounds, Bland (Maryland, High Court of Chancery 1841) wrote "merely plausible deductions, or bold flights of fancy, however ingenious or striking, cannot be received as matters of history, much less as judicially established truths."

Another earthwork in Ohio (Squier and Davis 1848) was found to have a chestnut tree growing on it with "not far from two hundred annual rings or layers to the foot." The age of this tree was estimated from half its diameter $(6.7 \mathrm{ft}$. or $2.0 \mathrm{~m})$ to be nearly 600 years old and the earthworks much older.

Several other sites outside of Ohio, both in the United States and Canada were also dated in this manner. In Virginia, a mound on the east bank of the Ohio River was reported to have a 700 to 800 year old white oak on its summit (Schoolcraft 1842). A native copper mine in Michigan was determined to be at least 395 years old, by determining the age of a tree stump found on a mound of mine tailings (Piggot 1867). Wyman (1868), writing in the American Naturalist, said that when attempting to determine the age of fresh-water shell heaps in the St. John's River of Florida: "No satisfactory data were found for determining the age of the shell-heaps. [...] The most trustworthy records are found in the forest trees growing upon the mounds. These give us a minimum age with some approach to accuracy." A tree at an abandoned Native American settlement in New Mexico was determined from ring counts to be 640 years old, although it was thought that the site was not that old (Anonymous 1876). In 1889, by counting the tree rings on a stump, an aboriginal cemetery in Simcoe County, Ontario, was determined to be at least 115 years old. Evidence from French tomahawks found at the site indicated that the cemetery was probably 17th Century (Hunter 1904). This study showed the importance of independent archaeological data in age estimations.

Recession rates (mass wasting) of the Mohawk River gorge in New York (Gilbert 1871) were estimated by dividing the length of the exposed roots of stunted eastern white cedars (Thuja occidentalis 
L.) growing on the cliff face by their age. Age was estimated by multiplying trunk diameter by the average growth rate determined by counting tree rings "from two sections of trunks."

McGee (1892) used tree aging to confirm the historical accounts of an earthquake centered near New Madrid, Missouri (1811-1813):

\footnotetext{
"the forest trees flanking the fissures and clothing the scarp give a trustworthy and fairly accurate date for the production of the minor topographic features-a date determined by much counting of annual rings to lie between seventy-five and eighty-five or ninety years ago."
}

Clearly many 19th Century archaeologists and geologists were comfortable with the idea of one ring equaling one year's growth.

\section{THE FINAL ARBITERS-I. STATE AND FEDERAL COURTS}

Although Bland, in 1830, had rejected the use of counting tree rings as a means of ascribing an age to a tree, a number of later cases heard in both state and federal courts did just that, both in boundary and trespass cases. In the United States v. White (District Court, N.D. California 1862) the United States argued that the termination of a boundary line was a tree (species not given) "with ancient marks upon it." It was determined that the marks were, "by counting the annulations," 20 to 25 years old and by a witness for the United States, 15 years old. As the original survey was done in 1835 , these results indicate that this tree may have been marked during the original survey. The Court, however, determined that "this circumstance [tree with ancient marks], in the absence of testimony showing it to have been marked at the time of the measurement as a corner, is wholly inconclusive, for it may have been marked previously or subsequently, or even at the time, to indicate the course but not the termination of the line." There was some dispute as to the age of the tree in question, but not the validity of counting tree rings.

In a trespass case, Shiffer $v$. Broadhead et al. (Supreme Court of Pennsylvania 1889), it was found that the defendants "In cutting and removing other trees which they had no right, and must have known they had no right to cut, they became trespassers." In 1867 Broadhead had purchased the rights to "all the white pine and hemlock timber (and no other) now being, standing or growing upon [. . .] the Broadhead lot." Broadhead and his co-defendants did not cut the trees until 1885 , and in doing so removed 314 trees that were in 1867 less than "ten inches and upwards in diameter at the top of a log twelve feet long, first cut from the stump," the minimum size for felling of white pine. The size of the trees, in 1867 was estimated by "deducting from the whole number of annual rings formed, seventeen of the outer rings, and then measuring the diameter of the inner portion remaining." These measurements were made at the behest of a lower court in 1887 that ruled:

\footnotetext{
"It is a well known fact that the age of a tree is readily ascertained by counting from the centre to the circumference of a cross cut or section of a tree, the successive rings formed annually one by one as the tree grows. There is no other method of ascertaining the age of a tree with accuracy, and in all cases where it becomes important to decide upon the age, growth and probable diameter of a tree at any given time, it is customary to count off from each side of the tree, beginning at the outside, the number of growths formed since the date in question. The growths that are left after deducting the number thus counted off, will give the age and size of the tree at the required date."
}

This ruling is clearly contrary to that of Patterson v. M'Causland (Maryland, High Court of Chancery 1841) and was cited along with Whitfield et al. v. the Rowland Lumber Company (Supreme Court of North Carolina 1910) in The Essentials of American Timber Law (Kinney 1917) as evidence that with regard to timber contracts "annual rings of growth exhibited by the stump have been recognized judicially as a means of determining the size of the trees at the time the contract was made."

The first use of tree rings for dating blazes on witness trees in the Supreme Court was that of Missouri v. Iowa (Supreme Court of the United States 1897). In an effort to "find and re-mark with proper and durable monuments such portions of the proper boundary line between the States of Missouri and Iowa [...] as have become obliterated", two members of the U.S. Coast and Geodetic Survey under the supervision of commissioners appointed by the Supreme Court resurveyed the boundary from the 40th to the 60th mile point during the spring of 1896 . The delineation 
of the 52nd mile point in the original 1849-1851 survey of Hendershott and Minor as marked by two witness trees; an elm and an oak "was more difficult and involved a much more extended investigation than for any point established by the commissioners." The oak had an unreadable blaze about five feet above the ground, and at its base, the letters "BX" were found rather than the "BL" as reported by Hendershot and Minor. The directions faced by the blazes also differed from what was expected. A section of the trunk was sent to the botanist Prof. McBride at the University of Iowa in an effort to ascertain the age of the tree. McBride determined that the tree was 70 yrs old and that an injury to the trunk had occurred when the tree was $c a$. 11 years old. Based on McBride's measurements the commissioners determined that "As the blaze shows a face of fully eight inches, it is evident it could not have been cut on a tree with a diameter of only five inches." The elm completely lacked the "BL" at its base and therefore the commissioners determined that these two trees "could not have been the witness trees as claimed."

In order to re-establish the boundary line between Tennessee and Virginia running from the White Top Mountain in the east to the Cumberland Gap in the west, commissioners appointed by the Court (Supreme Court of the United States 1903), attempted to identify those trees marked in the earlier surveys of 1802 and 1858/59. Blocks of wood were cut from several marked trees and sent to the United States Bureau of Forestry, where it was determined that the scars dated to 1858 and 1802 ; thus the authenticity of these witness trees was confirmed. ${ }^{7}$ Clearly, by the late 19th/early 20th Century, both state and federal courts recognized the validity of aging trees and dating blazes by ring counts.

\section{THE FINAL ARBITERS-II. THE DIVISION OF FORESTRY, UNITED STATES DEPARTMENT OF AGRICULTURE}

Because of the importance of being able to identify witness trees in boundary disputes, Bernhard

\footnotetext{
${ }^{7}$ For further information on Missouri $v$. Iowa and Tennessee v. Virginia, see Scott (1918).
}

E. Fernow, third USDA Division of Forestry chief, entered the debate. Fernow was involved in putting to rest any resistance to the idea that tree rings could be used to accurately age a tree. In a letter to The Nation (1888a) he wrote that in an attempt "To allay all doubts, the Forestry Division of the Department of Agriculture is collecting material upon which to decide this very important question, and seeks the co-operation of all those who are in position to forward sections of trees with well authenticated record." Fernow asked for help from the readers of The Nation to "engage their co-operation in supplying evidence for or against the theory of annual rings."

Fernow (1888b) in the Annual Report of the Division of Forestry for 1887 addressed the difficulties of distinguishing tree rings especially in diffuse porous wood:

\footnotetext{
"In the wood of conifers, and in that of deciduous-leaved woods in which the vessels (appearing as pores on a transverse cut) are most frequent in the spring wood, the annual ring is usually very distinctly visible; while those woods which, like birch, linden, maple, etc., have the pores (vessels) evenly distributed throughout the annual ring growth, the distinction is not so marked."
}

Fernow also asserted that the presence of false rings had led some to doubt that the age of a tree could be ascertained by counting the number of annual rings:

\footnotetext{
"Sometimes the gradual change in appearance of the annual ring from spring to autumn wood, which is due to the difference of its component elements, is interrupted in such a manner that seemingly a more or less pronounced layer of autumn wood can be recognized, which again gradually changes to spring or summer wood and then finishes with the regular autumn wood. This irregularity may occur even more than once in the same ring. Such double or counterfeit rings, which can be distinguished from the true annual rings by a practiced eye with the aid of a magnifying glass, have led to the notion that the annual rings are not a true indication of age."
}

He attributed the formation of false rings to such factors as defoliation, or sudden changes in climatic conditions such as temperature or rainfall. In his letter to The Nation, Fernow (1888a) also stated that great ages sometimes reported for trees were the result of "a prejudice against the accepted theory or a love for new discoveries and a lack of sharp observation on the part of the reporter." Gross exaggerations include those of a giant se- 
quoia determined by counting tree rings to be 6,300 years old (The Coshocton Democrat [Ohio] 1863), and a baldcypress buried in the Mississippi Delta to be 5,700 years old (Daily Gazette and Bulletin [Pennsylvania] 1879; The Decatur Daily Review [Illinois] 1879; Marion Daily Star [Ohio] 1882a). The age of the sequoia was not, however, determined directly by counting the number of rings but by determining the number of rings per inch from a small block and then extrapolating for half the diameter (15 ft. or $4.6 \mathrm{~m}$ ) (Haines 1863). The antiquity of these trees as well as other species was of great interest to the general public as numerous newspaper reports attested. Fernow went on to say that "so far, no evidence has come before me which would shake my belief in the accepted theory [one ring equals one years growth], upon which the whole scientific system of German forestry is practically based."

In 1890, Frederick Ward Putnam, Curator of the Peabody Museum of American Archaeology and Ethnology at Harvard University from 1875 to 1909, also quoted a letter from Bernard Fernow which stated his belief that "anybody and everybody [was] an incompetent observer of tree growth who would declare that, in the temperate zones, the annual ring is not the rule, its omission or duplication the exception." Putnam also sought advice from Charles Sprague Sargent, Director of Harvard's Arnold Arboretum about the validity of using tree rings in aging. Sargent wrote back: "I have never seen anything to change my belief that in trees growing outside of the tropics each layer of growth represents the growth of one year; and as far as I have been able to verify statements to the contrary, which have appeared of late years, I am unable to place any credence in any of them." Four years later in 1894 Hotchkiss reported in the Botanical Gazette that "the number of growth layers" of witness trees from the Henry Banks patent of 1787 in West Virginia "agreed in number exactly with the record." In an even earlier legal treatise, The Complete Works of Edward Livingston on Criminal Jurisprudence (Edwards 1873), it was stated: "The number of concentric circles in the wood that has grown over the mark [blaze] is substantive evidence of the number of years that have elapsed since it was made."
The Naugatuck Daily News [Connecticut] announced on November 4, 1897 in the article, "About tree rings. Correctness of the theory that they denote age proved", that the Forestry Division of the Department of Agriculture had published a pamphlet, The Annual Ring, giving their official support to the position that the age of a tree could be determined by counting the number of tree rings. The full name of this circular by Fernow (1897) was the Age of Trees and Time of Blazing Determined by Annual Rings. In it Fernow made a forceful case:

\footnotetext{
"The correctness of the rings as record forms a fundamental tenet in the science of forestry as practiced abroad, and has within the last half century been verified by tens of thousands of countings made in trees of all European forest species in almost all parts of Europe, and on trees where time of seeding, planting, age of plant stock, etc., were accurately known from permanent records. Generally these countings were made for purposes other than the mere determination of age, but nevertheless serve today as incontrovertible, accurate, evidence at least for Europe and its species. But there are also in the same countries, especially France and Germany, thousands of similar records for American species, White Pine, Red Oak, etc. which in all cases bear out exactly the same results. In addition, we have in our own country many hundred countings on record and thousands more not permanently recorded, proving the same for the forest species of the temperate zone in the United States."
}

Fernow attributed differences in ring numbers along different radii to "the inability of the eye to detect an extremely narrow but otherwise well defined ring" or the "actual absence of one or more rings along a given radius." The absence of rings was ascribed to unfavorable conditions such as dense shade or injury by coal smoke. Fernow also believed that in most cases false rings could be detected with the proper magnification and a correct ring count could be obtained. In extremely stunted trees with rings made up of only a few cells, only an approximation of the correct age, however, was deemed possible. With regard to dating "blazes," Fernow stated that "By a careful study of the entire cross section the time may usually be approximated to within a very few years." Finally this issue had been put to rest opening the way for the unimpeded development of dendrochronology in the 20th Century. 


\section{EPILOGUE}

Although in most states, witness trees have not survived to the present, their identification may be still important when retracements of original surveys are made. For example, a yellow-poplar (Liriodendron tulipifera L.) marked as a witness tree in an 1805 GLO survey in Alabama, was positively identified in a 1996 retracement, and allowed for the reestablishment of a section corner (Robillard et al. 2002). A recent case in England also illustrates the importance of dendrochronology in resolving boundary disputes (Winchester 2003). A Lawson's cypress (Chamaecyparis lawsoniana (A. Murr.) Parl.) hedge separating two properties in Bedfordshire was composed of two non-parallel sections joined by a dogleg. Dendrochronological analysis revealed that both sections of the hedge were the same age, but a band of disturbed cells found in the fourth year of growth in the disputed section of the hedge indicated that the trees had most likely been transplanted. Also, the dogleg was composed of trees planted at a later date. After confronting his neighbor with the evidence, "The neighbour admitted that he had moved the hedge from its original boundary position and withdrew his claim to the extra strip of land."

\section{ACKNOWLEDGMENTS}

Thanks are extended to Monty Maldonado, USDA Forest Service for providing a copy of the article: Age of Trees and Time of Blazing Determined by Annual Rings, and the following who reviewed various drafts: Dr. Michael Folkoff (Salisbury University), Cheryl Hartnett (also for translating portions of Duhamel du Monceau), Dr. Doug Larson (University of Guelph) and four anonymous reviewers. This paper would not have been possible without the electronic resources provided by American Journeys, Bibliography of Dendrochronology (http://www01.wsl.ch/dendrobiblio/), Canadiana.org (Canadian Institute for Historical Microreproductions), Gallica (Bibliothèque nationale de France), Google ${ }^{\mathbb{T N}}$ Book Search, the Library of Congress American Memory, the LuEsther T. Mertz Library (New York Botanical Garden) Rare Book Digitization Project, the Making of America (Uni- versity of Michigan and Cornell University), the Maryland State Archives, Michigan County Histories, The Nation Digital Archive, NewspaperArchives.org, and the Royal Society (the UK National Academy of Science). The Interlibrary Loans Department of the Blackwell Library (Salisbury University) also provided invaluable assistance in acquiring many of the references.

\section{REFERENCES CITED}

Andreas, A. T.

1882 History of the State of Nebraska. The Western Historical Co., Chicago.

Anonymous

1844 The longevity of trees. The North American Review 59(124):189-238.

1859 How to tell the character of past seasons. Scientific American 1(11): 178

1876 Homes of the American aborigines. The Galaxy 21: 513-520.

1890 The age of trees. The Manufacturer and Builder 22(5):107.

1904 Biographical and Genealogical History of Southeastern Nebraska, Volume 1. The Lewis Publishing Company. Chicago \& New York.

Babbage, C.

1838 The Ninth Bridgewater Treatise. A Fragment, ed. 2. John Murray, London. Reprinted by Frank Cass \& Co. Ltd., London, 1967.

Baldwin, A. S

1884 The age of trees. Popular Science Monthly 24:554555.

Bliss, P.

1894 A Treatise upon the Law of Pleading, ed. 3. Revised and Annotated by B. F. Johnson. West Publishing Co., St. Paul.

Bowman, J. E.

1832 On the longevity of the yew, as ascertained from actual sections of its trunk. Magazine of Natural History 1:28-35.

Bradley, C. B.

1887 Correspondence - the age of the sequoias. The $\mathrm{Na}$ tion 45:504.

Britton, N. L.

1879 Notes on the relative age and dimensions of a number of different trees. Bulletin of the Torrey Botanical Club 6:309-310.

Brooklyn Eagle (New York)

1887 The rings in trees. 14, Aug., p. 2, c. 5.

Card, F. W.

1898 An observation on annual rings. Papers and Proceedings of the Nebraska Academy of Sciences, 1896. In Proceedings and Collections of the Nebraska State Historical Society. Second Series, Volume 2:243244. State Journal Company, Printers, Lincoln. 
Charnay, D.

1887 The Ancient Cities of the New World. transl. J. Gonino and H. S. Conant. Harper and Brothers, New York.

Child, A. L.

1882 Annual growth of trees. Popular Science Monthly 22: 204-206.

1883 Concentric rings of trees. Popular Science Monthly 24:259-261.

Coshocton Democrat, The (Ohio)

186325 Nov., p. 1, c. 2.

18716 June, p. 4, c. 2.

Daily Gazette and Bulletin (Williamsport, Pennsylvania)

187925 Nov., p. 2, c. 3.

18947 June, p. 3, c. 2.

Dall, C. H.

1887 Correspondence-age of the sequoias. The Nation 45:415.

Darwin, E.

1800 Phytologia, or the Philosophy of Agriculture and Gardening. J. Johnson, London.

DaVinci, L.

1651 Treatise on Painting. Codex Urbinas Latinus 1270. Translated and annotated by A. Philip McMahon, with an introduction by Ludwig H. Heydenreich, Volume I-Translation. Princeton University Press, Princeton. 1956.

Decatur Daily Republican, The (Illinois)

188214 July, p. 1, c. 3.

Decatur Daily Review, The (Illinois)

1879 Antiquity of Man, 13 Dec., p. 2, c. 6.

Defiance Democrat (Ohio)

18695 June, p. 1, c. 4.

District Court, N.D. California

1862 United States v. White. Case No. 16,681. U.S. Dist. Lexis 62; 28F. Cas. 576; 1 Hoff. 58.

Douglass, A. E.

1909 Weather cycles in the growth of big trees. Monthly Weather Review 37:225-237.

1914 A method of estimating rainfall by the growth of trees. Bulletin of the American Geographical Society 46:321-335.

1920 Evidence of climatic effects in the annual rings of trees. Ecology 1:24-32.

1922 Some aspects of the use of the annual rings of trees in climatic study. The Scientific Monthly 15:5-21.

1929 The secret of the Southwest solved by talkative tree rings. National Geographic 56(6):736-770

Dudley, P. H.

1886 Duct formation in chestnut wood. Bulletin of the Torrey Botanical Club 13(6):91-92.

Duhamel du Monceau, H.-L.

1758 La physique des arbres. H. L. Guerin and L. F. Delatour, Paris.

E.L., Sr.

1879 Long Island trees. Brooklyn Eagle, 23 Feb., p. 2.
Eaton, A.

1828 Botanical Grammar and Dictionary; Translated from the French of Bulliard and Richard. Websters and Skinners, Albany.

Fernow, B. E.

1888a Ring-growth in trees. The Nation (January 12):29.

1888b Annual Report of the Division of Forestry for 1887. Government Printing Office, Washington.

1897 Age of Trees and Time of Blazing Determined by Annual Rings. United States Department of Agriculture, Division of Forestry, Circular No. 16.

Fewkes, J. W.

1915 A sun temple in the Mesa Verde National Park. Art and Archaeology 2:341-346.

Geo. A. Ogle \& Co.

1903 Standard Atlas of Manistee County, Michigan. Geo. A. Ogle \& Co., Chicago.

Getty, H. T.

1935a New dates from Mesa Verde. Tree-Ring Bulletin $1(3): 21-23$.

1935b New dates for spruce tree house, Mesa Verde. TreeRing Bulletin 1(4):28-29.

Gilbert, G. K.

1871 Notes of investigations at Cohoes with reference to the circumstances of the deposition of the skeleton of Mastodon. State Cabinet of Natural History, Albany, N.Y., 21st Annual Report:129-148.

Gray, A.

1853 The Botanical Text-Book, an Introduction to Scientific Botany, both Structural and Systematic. For Colleges, Schools \& Private Students, ed. 4. George P. Putnam \& Co., New York.

1876 Darwiniana. Essays and Reviews Pertaining to Darwinism. D. Appleton and Co., New York.

Grew, N.

1682 The Anatomy of Plants. With an Idea of a Philosophical History of Plants, and Several Other Lectures Read Before the Royal Society. Printed by W. Rawlin, for the Author. Johnson Reprint Corp., New York and London. 1965.

Haines, R. R.

1863 Correspondence - a California tree 6,300 years old! Scientific American 8(14):214.

Hartford Daily Courant (Connecticut)

185627 September, p. 3.

Haury, E. W.

1934 Climate and human history. Tree-Ring Bulletin 1(2): 13-15.

Hill, J.

1770 Construction of Timber, from its Early Growth; Explained by the Microscope, and Proved from Experiments, in a Great Variety of Kinds: in Five Books. Printed for the Author, London.

Hotchkiss, J.

1894 The growth of forest trees illustrated from marked corners 107 years old. Botanical Gazette 19:379380. 
Hough, F. B.

1878 Growth of wood in different years. In Report upon Forestry. Government Printing Office, Washington: $38-40$.

Hunter, A. F.

1904 Notes on Sites of Indian Villages. Warwick Bro's \& Rutter, Toronto.

Jeffrey, E. C.

1911 David Pearce Penhallow. Botanical Gazette 51:142144.

Kalm, P.

1773 Travels into North America, ed. 2, transl. J. R. Forster. 2 vols. Printed for T. Lowndes. London.

Kinney, J. P.

1917 The Essentials of American Timber Law. Monumental Printing Co., Baltimore.

Lafayette Advertiser, The (Louisiana)

1894 Of general interest, 14 July, p. 6, c. 5.

Leewenhoeck, A.

1683 Letter from Mr. Anthony Leewenhoeck of Delft to Mr. R.H. concerning the appearances of several woods, and their vessels. Philosophical Transactions of the Royal Society of London 12:197-208.

1798 \& 1807 Select Works of Antony Van Leeuwenhoek, Containing His Microscopical Discoveries in Many of the Works of Nature. 2 vols. S. Hoole transl. Printed by Henry Fry, Finsbury-Place, London. Arno Press. New York. 1977.

Lewis, E.

1873 The longevity of trees. Popular Science Monthly 3: 321-334.

Livingston, E.

1873 The Complete Works of Edward Livingston on Criminal Jurisprudence. 2. vols. The National Prison Association, New York. Reprinted by Patterson Smith Publishing Co., Montclair, 1968.

Marion Daily Star, The (Ohio)

1881 The earth's great age, 2 June. p. 3, c. 3.

1882a Facts for the curious, 12 April. p. 2, c. 5.

1882b 14 April, p. 3, c. 3

Marbury, W. L.

1905 High Court of Chancery and the Chancellors of Maryland. In Report of the Tenth Annual Meeting of the Maryland State Bar Association, edited by J. U. Dennis, Press of Pearre E. Crowl Co., Baltimore. pp. 137-155.

Marshall, W.

1785 Planting and Ornamental Gardening; A Practical Treatise. Printed for J. Dodsley, Pall-Mall, London.

Maryland, High Court of Chancery

1841 Reports of Cases Argued and Adjudged in the High Court of Chancery of Maryland, Volume 3. Cushings \& Bailey. Baltimore.

McCulloh, J. H.

1829 Researches, Philosophical and Antiquarian, Concerning the Aboriginal History of America. R. J. Kennett, London \& Fielding Lucas Jr., Baltimore.
McGee, W. J.

1892 A fossil earthquake. Bulletin of the Geological Society of America 4:411-415.

Michaux, F. A.

1817-1819 North American Sylva, transl. A. L. Hillhouse. 3 vols. Sold by Thomas Dobson, Philadelphia; Printed by C. d'Hautel, Paris.

Mitchell, J.

1827 Dendrologia. Printed for the Author by R. Aked, Low-Street, London.

Montgomery, J. H.

1884 Botanical Notes. The Chautauquan 4(4):227-228.

Morgan, J. A.

1882 The Principles of the Law of Evidence. 2 vols. Frederick D. Linn \& Co., Jersey City.

Murchison, R. I.

1861 Address to the Royal Geographical Society of London. Proceedings of the Royal Geographical Society of London 5(4):146-217.

Nash, S. E.

1999 Time, Trees, and Prehistory. University of Utah Press, Salt Lake City.

2003 Not so talkative tree rings. In Picking the Lock of Time, edited by J. Truncer, University Press of Florida. Gainsville.

Naugatuck Daily News (Connecticut)

1897 About tree rings. Correctness of the theory that they denote age proved, 4 Nov., p. 4, c. 3.

New York Times, The

1882 The woods of America, 22 Oct., p. 13. c. 1-2.

Nuttall, T.

1827 An Introduction to Systematic and Physiological Botany. Hilliard and Brown, Cambridge; Hilliard, Gray, Little, and Wilkins, and Richardson and Lord, Boston.

Olean Democrat, The (New York)

1890 Annual rings and age of a tree, 12 June, p. 6, c. 4.

Penhallow, D. P.

1885 The relation of the annual rings of exogens to age. Canadian Record of Science 1:162-175.

Piggot

1867 The copper region of Lake Superior. Scientific American 17(22):338.

Pinchot, G.

1908 The Use Book. Regulations and Instructions for the Use of the National Forests. U.S. Department of Agriculture, Forest Service. Government Printing Office, Washington.

Putnam, F. W.

1890 Prehistoric remains in the Ohio Valley. The Century Magazine 39(5):698-703.

Rees, A.

1819 The Cyclopaedia; or, Universal Dictionary of Arts, Sciences and Literature. Longman, Hurst, Rees, Orme and Brown, London.

Robillard, W. G., D. A. Wilson, and C. M. Brown

2002 Evidence and Procedures for Boundary Location. John Wiley \& Sons, Inc., New York. 
Roget, P. M.

1834 Animal and Vegetable Physiology, Considered with Reference to Natural Theology. W. Pickering, London.

Sandusky Daily Register (Ohio)

1891 The age of trees, 14 Feb., p. 2, c. 7.

1895 Rings as marks of tree growth, 14 Jan., p. 7, c. 4.

Schoolcraft, M.

1842 Account of the mound at Grave Creek Flats in Virginia. Transmitted by Sir J. E. Alexander. Journal of the Royal Geographical Society of London 12:259260.

Scott, J. B. (ed.)

1918 Judicial Settlement of Controversies between States of the American Union, Volume 2. Oxford University Press, New York.

Sheldon, A. E.

1904 Semi-Centennial History of Nebraska. The Lemon Pub. Co., Lincoln.

Smith, J. E.

1814 An Introduction to Physiological and Systematical Botany. Bradford \& Read, Boston.

Smith, P. C.

1883 The age of trees. In Correspondence. Popular Science Monthly 23(4):552-553.

Squier, E. G., and E. H. Davis

1848 Ancient Monuments in the Mississippi Valley. Bartlett \& Welford, New York.

Stevens Point Journal, The (Wisconsin)

18782 Mar., p. 1, c. 3

188528 Nov., p. 4, c. 6-7.

Supreme Court of North Carolina

1910 V. A. Whitfield et al. v. the Rowland Lumber Company. 152 N.C. 211; 67 S.E. 512; 1910 N.C. Lexis 242.
Supreme Court of Pennsylvania

1889 J. B. Shiffer v. J. A. Broadhead et al. No. 47. 126 Pa. 260; 17 A. $592 ; 1889$ Pa. Lexis 866.

Supreme Court of the United States

1897 Missouri v. Iowa. No. 6. Original. 165 U.S. 118; 17 S. Ct. 290; 41 L. Ed. 655; 1897 U.S. Lexis 1955.

1903 Tennessee v. Virginia. No. 6. 190 U.S. 64; 23 S. Ct. 827; 47 L. Ed. 956; 1903 U.S. Lexis 1541.

Tredgold, T.

1820 Elementary Principles of Carpentry. Printed for J. Taylor, at the Architectural Library, №. 59, High Holborn, London.

Twining, A. C.

1833 On the growth of timber. Letter to the Editor. The American Journal of Science \& Arts 24:391-393.

United States, Continental Congress

1785 An ordinance for ascertaining the mode of disposing of lands in the Western Territory. New York: s.n.

Winchester, V.

2003 The peripatetic hedge: a case for dendrochronological dating. Science and Justice 43:23-28.

Worbes, M

2002 One hundred years of tree-ring research in the tropics-a brief history and an outlook to future challenges Dendrochronologia 20:217-231.

Wyman, J.

1868 On the fresh-water shell-heaps of the St. Johns River, East Florida. American Naturalist 2:449-463.

Yates County Chronicle (Penn Yann, New York)

188412 March. p. 4, c. 2.

Received 2 August 2005; Accepted 3 October 2006 